Case Report

\title{
A Case of Beckwith-Wiedemann Syndrome with Polyhydramnios
}

\section{Suatu Kasus Sindrom Beckwith-Wiedemann dengan Polihidramnion}

\author{
Yusrawati, Reno Muhatiah \\ Department of Obstetrics and Gynecology \\ Faculty of Medicine Universitas Andalas/ \\ Dr. M Djamil Hospital \\ Padang
}

\begin{abstract}
Objective: To report a rare case of Beckwith-Wiedemann Syndrome with polyhydramnios.

Methods: Reporting a case of Beckwith-Wiedemann syndrome with polyhydramnios.

Results: Case of Mrs. Y, 27 years old woman, $\mathrm{G}_{2} \mathrm{P}_{1} \mathrm{~A}_{0} \mathrm{~L}_{1}$ preterm pregnancy (30-31 weeks) with polyhidramnios. From ultrasound found renomegaly, bilateral hyperechogenic polycystic kidney, and the karyotype result was 46,XX. Caesarean section was performed due to fetal distress. A female baby was born by caesarean section with birth weight of 1300 grams, 37 centimeters of body length, and APGAR score of 6/8. The congenital anomalies found were hepatomegaly, renomegaly, bilateral hyperechogenic renal polycystic, low set ears. The baby was died in NICU on day care $5^{\text {th, with sus- }}$ pected of sepsis.

Conclusion: Prenatal diagnosis of Beckwith-Wiedemann syndrome on fetus with polyhydramnios.

[Indones J Obstet Gynecol 2017; 5-3: 185-188]

Keywords: amniocentesis, beckwith-wiedemann syndrome, polyhydramnios, prenatal diagnostic, USG
\end{abstract}

\begin{abstract}
Abstrak
Tujuan: Melaporkan kasus sindrom Beckwith-Wiedemann pada polihidramnion.

Metode: Melaporkan kasus sindrom Beckwith-Wiedemann dengan polihidramnion.

Hasil: Kasus Ny. Y usia 27 tahun, G2P1AoH1 gravid preterm (30 - 31) minggu dengan polihidramnion. Pada pemeriksaan ultrasonografi dijumpai renomegali, hiperekogenisitasginjal, polikistik ginjal bilateral, hasil analisa kromosomnya 46,XX. Dilakukan seksio sesarea atas indikasi fetal distres. Lahir bayi perempuan, BBL 1300 gram, PBL 37 sentimeter, Apgar Skor 6/8. Terdapat kelainan kongenital: hepatomegali, renomegali, polikistik ginjal bilateral hiperekogenik, dan low set ear. Bayi meninggal pada hari kelima rawatan di NICU dengan dugaan sepsis.
\end{abstract}

Kesimpulan: Diagnosis prenatal Beckwith-Wiedemann syndrome dengan polihidramnion.

[Maj Obstet Ginekol Indones 2017; 5-3: 185-188]

Kata kunci: amniosintesis, beckwith-wiedemann syndrome, polihidramnion, USG

\section{INTRODUCTION}

Polyhydramnios is defined as AFI $\geq 25$ centimeters or maximum vertical pocket (MVP) $\geq 8$ centimeters at AFI $<25$ centimeters. ${ }^{1}$ The incidence of polyhydramnios is approximately $1-2 \%$ in pregnancy. The etiologies of polyhydramnios include fetal anomalies, maternal diabetes, and idiopathic. It is estimated that $50 \%$ of cases are idiopathic. Polyhydramnios is known to be associated with an increased risk of poor pregnancy outcomes such as preterm labor, aneuploidy, sectio cesarean, and perinatal death. Congenital disorder that accompanies the disorder of the central nervous system, gastrointestinal tract, heart, and genitourinary tract. $^{2,3}$
The incidence of abnormalities of the urinary tract that is 1-4 in 1000 pregnancies, and $15-20 \%$ of congenital abnormalities when prenatal diagnosis. ${ }^{4,5}$ Bilateral enlarged hyperechogenic fetal kidneys are considered as diagnostic dilemma. If accompanied with oligo-or anhidramnios, the prognosis is usually very ugly. ${ }^{6}$ Polyhydramnios accompanied with bilateral enlarged hyperechogic fetal kidneys renomegaly may be caused by some disorders including Beckwith-Wiedemann syndrome, Perlman Syndrome, Adult Polycystic Kidney Disease, Infantile Polycystic Kidney Disease, and Trisomy 13.6 We present a case of patient with Beckwith-Wiedemann syndrome. 


\section{CASE}

A 27-year-old femalewas referred to Dr. M. Djamil Padang Hospital on October 26, 2015 due to shortness of breath. She was diagnosed with $\mathrm{G}_{2} \mathrm{P}_{1} \mathrm{~A}_{0} \mathrm{H}_{1}$ preterm pregnancy 30-31 weeks, polyhydramnios, intrauterine single live fetus. Ultrasound examination revealed fetal biparietal diameter of 75 milimeters, humerus length of 49 milimeters, femur length of 60 milimeters, abdominal circumference of 258 milimeters, estimated fetal weight of 1200 to 1300 grams, amniotic fluid index (AFI) 35.5 centimeters. Ultrasonography examination demonstrated bilateral enlarged polycystic hyperechogenickidneys.

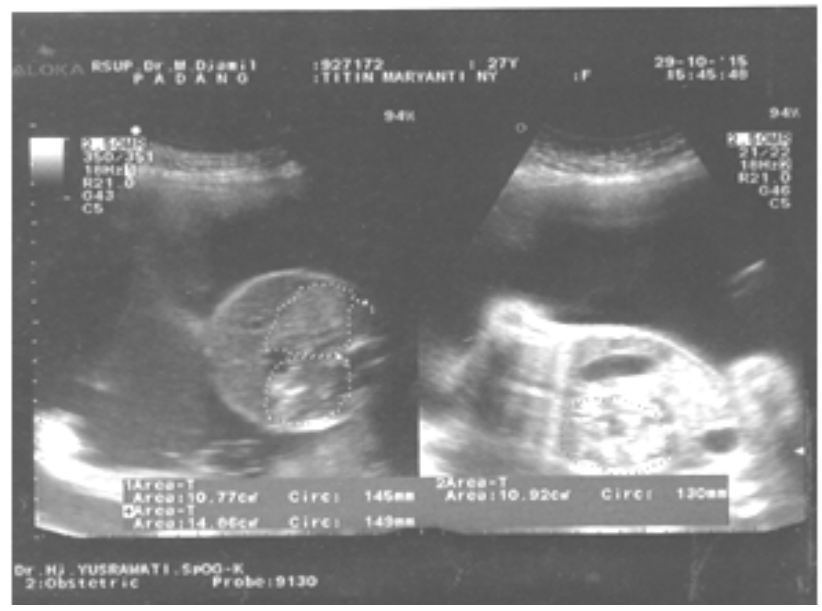

Figure 1. Polyhydramnios. Renomegaly, Polycystic Kidney Bilateral

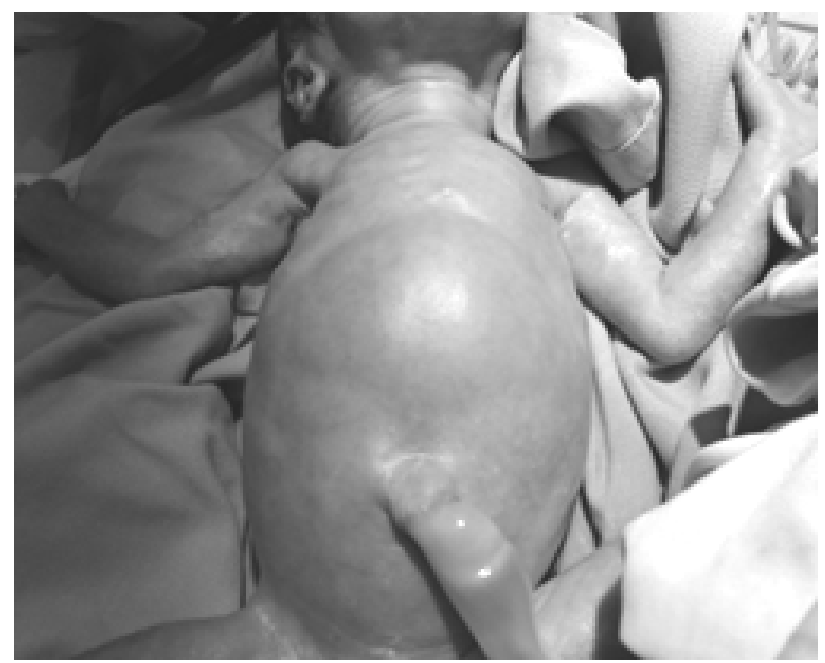

Hepatomegaly and renomegaly
Amnioreduction and amniotic fluid analysis were performed. The analysis revealed a karyotypes of 46,XX. No major structural abnormality was found (Figure 2).

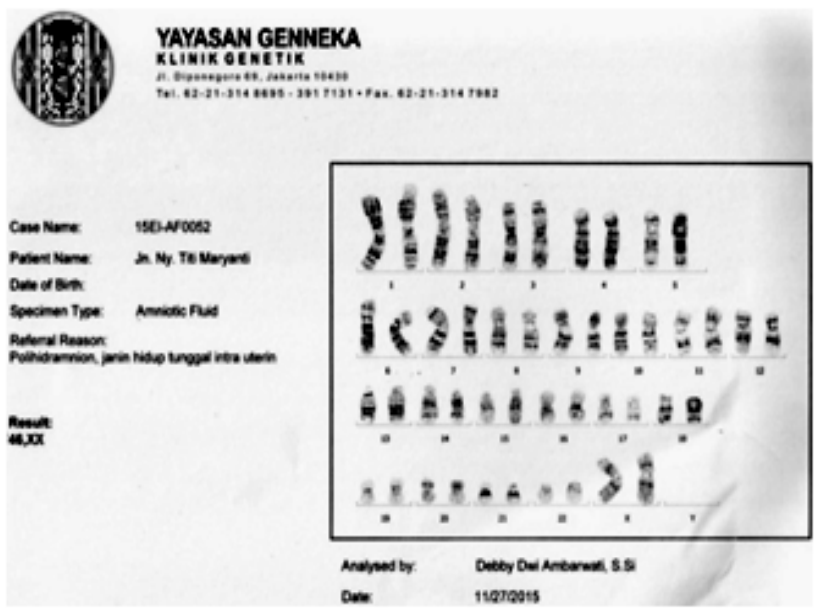

Figure 2. The Results of Chromosome Analysis

During treatment, a non reassuring NST (nonstresstest) was observed. Subsequently, cesarean section was performed. A baby girl was born with birth weight and body length of 1300 grams and 37 centimeters, respectively. Her Apgar score was $6 / 8$. Low set ears, anterior ear creases, hepatomegaly, and renomegaly were present. The placenta was $14 \times 13 \times 3.5$ centimeters, weighing 350 grams, the cord length was 40 centimeters, paracentral insertion, no abnormality found in the

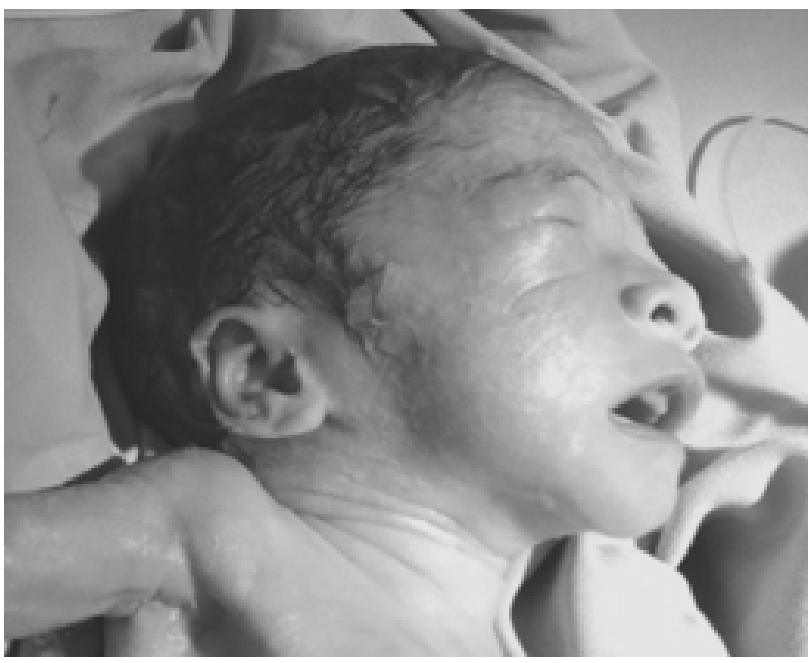

Anterior ear lobe creases (+)

Figure 3. Hepatomegaly, Renomegaly and Ear Lobe Creases of the Baby. 
placenta and umbilical cord. Baby was cared in the NICU due to respiratory distress which was caused by hyaline membrane disease.

\section{DISCUSSION}

In our case, the patient, Mrs. T, 27 years old, diagnosed with polyhydramnios at 30-31 weeks of pregnancy. Ultrasonographic examination revealed AFI of 35.5 centimeters (severe polyhydramnios), renomegaly, hyperechogenic and bilateral polycystic kidneys.

The analysis demonstrated a karyotypes of 46,XX. Congenital abnormalities may be present in these patient closer towards Beckwith-Wiedemann syndrome (BWS), which is an abnormality in the short arm of chromosome 11, 11p15 which causes over activity of gene IGF-2 and / or the absence of copying active CDKN1C (inhibitor of cell proliferation).

For the diagnosis of BWS, there should be three major findings or two major and one minor finding. The findings are listed in Table $1 .^{7}$ In this case, the major findings that we found were anterior ear lobe creases (folds in front of the ear lobe), visceromegaly (renomegaly, hepatomegaly), and the minor finding is polyhydramnios.

Chitty LS et al suggested the differential diagnosis in case of enlargement hyperechogenic kidney with normal amniotic fluid or increased, which is shown in Table 2.

Table 1. Major and Minor Findings of Beckwith-Wiedemann Syndrome

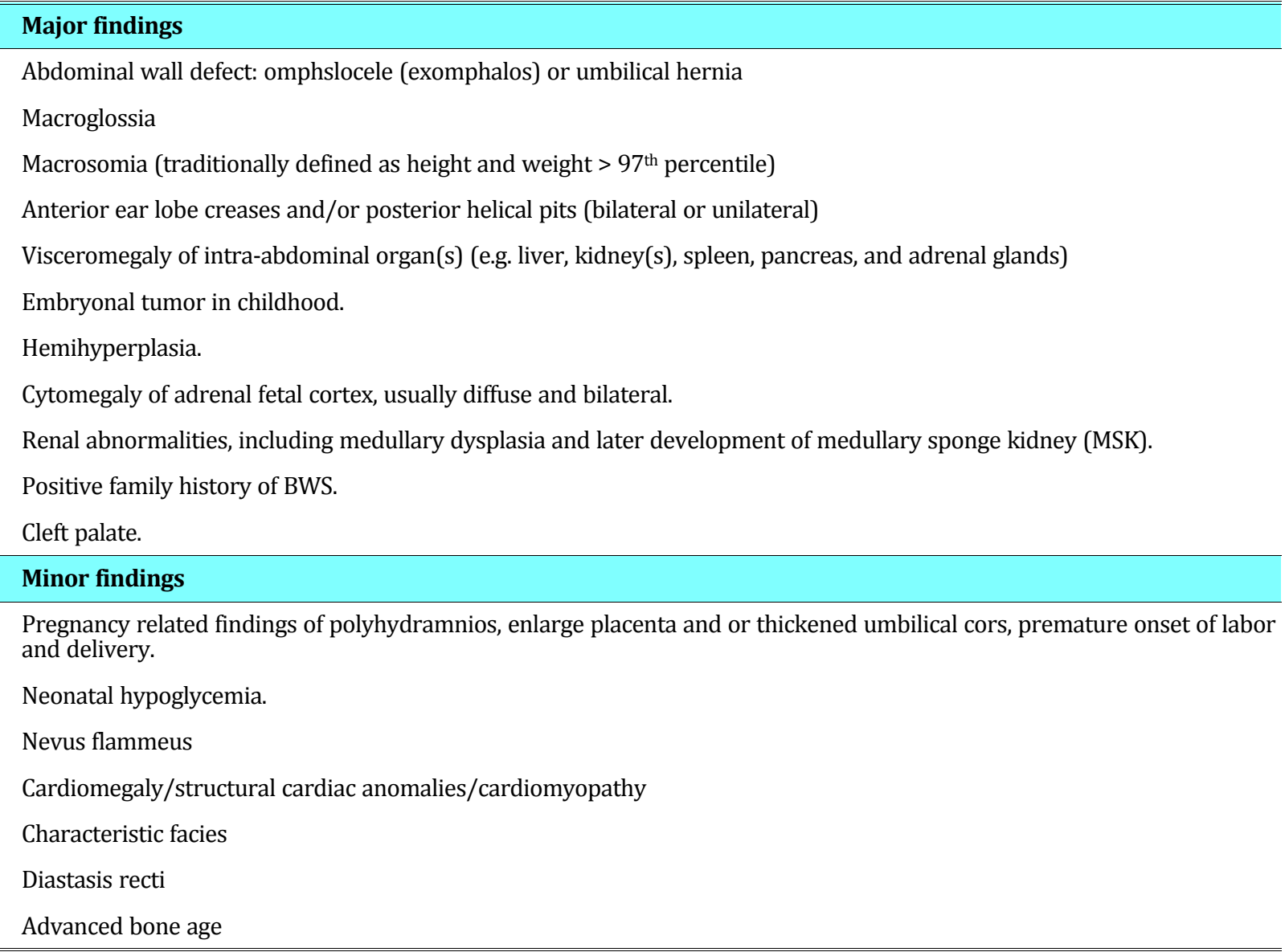


Table 2. Overview of the Prenatal Diagnosis of Fetal Echogenic Kidney Enlargement. 6

\begin{tabular}{|c|c|c|c|c|c|}
\hline & Beckwith* & Perlman & APCKD & IPCKD & Trisomy 13 \\
\hline Renomegaly & + & + & + & + & + \\
\hline Increased echogenicity & + & + & + & + & + \\
\hline Renal cysts & \pm & - & + & - & - \\
\hline Mild hydronephrosis & - & \pm & - & - & - \\
\hline Polyhydramnios & + & + & - & - & - \\
\hline Oligohydramnios & - & - & rare & common & - \\
\hline Generalized organomegaly & + & + & - & - & - \\
\hline Macrosomia & + & + & - & - & - \\
\hline Macroglossia & + & - & - & - & - \\
\hline Hemihypertrophy & + & - & - & - & - \\
\hline Omphalocele & + & - & - & - & - \\
\hline Other anomalies & - & & - & - & + \\
\hline Consanguinity & - & + & - & + & - \\
\hline Family history in parent/grandparent & \pm & - & + & - & - \\
\hline Family history in sibling & \pm & + & - & + & - \\
\hline
\end{tabular}

*Beckwith=Beckwith-Wiedemann syndrome; APCKD=adult polycystic kidney disease; IPCKD=infantile polycystic kidney disease

Amnioreduction was performed due to breathlessness and abnormal maternal chromosomes examination. During treatment, fetal distress was observed, thereby cesarean section was performed. According to the literature genetic examination of Beckwith-Wiedemann syndrome is very complex, causing difficulties in molecular diagnosis, and diagnosis is based on clinical findings. ${ }^{8}$

Patient was discharged on the $3^{\text {rd }}$ day postoperative with good condition, while the baby died on day $5^{\text {th }}$ of treatment due to sepsis. Severe polyhydramnios is associated with unfavorable outcomes, including as low Apgar score, fetal death, fetal distress, and neonatal death. ${ }^{9}$ Weksberg $\mathrm{R}$ et al suggested that infant death could arise from complications such as hypoglycemia, prematurity, cardiomyopathy, macroglossia, or tumor. ${ }^{7}$

\section{CONCLUSION}

Beckwith-Wiedemann syndrome is a rare disorder caused by a defect on chromosome $11 \mathrm{p} 15$ mold. Prenatal diagnosis using ultrasound is necessary to detect abnormal findings.

\section{REFERENCES}

1. Cunningham FG, Leveno KJ, Bloom SL, Spong CY, Dashe JS, Hoffman BL, et al. Amnionic Fluid. In Williams Obstetrics 24th ed. USA: The McGraw Hill companies, Inc. 2014.

2. Biggio RJr, Wenstrom KD, Dubard MB, Cliver SP. Hydramnios prediction of adverse perinatal outcome. Obstet Gynecol, 199; 94: 773.

3. Barkin SZ, Beckett Court, Pretoius DH, Johnson ML. Severe Polyhydramnios: incidence of anomalies. Am J Roentgenol, 1987; 148: 158.

4. Grandjean H, Larroque d, Levi S. The performance of routine ultrasonographic screening of pregnancies in the eurofetus Study. Am J Obstet Gynecol. 1999; 181: 446-54.

5. Elder JS. Antenatal hydronephrosis. Fetal and neonatal management. Pediatr Clin North Am. 1997; 44: 1299-1321.

6. Chitty LS, Griffin, DR, Johnson P, Neales K. The differential diagnosis of enlarged hyperechogenic kidneys with normal or Increased liquor volume: report of five cases and review of the literature. Ultrasound Obstet Gynecol, 1991; 1: 11521.

7. Weksberg R, C Shuman, Beckwith JB. Beckwith-Wiedemann syndrome. Eur J Hum Genet. 2010; 18(1): 8-14.

8. Vora N, Bianchi DW. Genetic considerations in the prenatal diagnosis of over growth syndromes. Prenatal Diag 2009; 29: 923-9.

9. KC Chen, LIOUJD, TH Hung, Kuo DM, Hsu JJ, Hsieh CC. Perinatal Outcomes of Polyhydramnios without Fetal Congenital Anomalies Associated after the Gestational Age of 20 weeks. Chang Gung Med J, 2005; 28: 222. 